\title{
Penanaman Nilai Moral- Spiritual Pada Anak Usia Dini Melalui Cerita Fabel dalam Surat Al-Fiil
}

\author{
Intan Puspitasari' ${ }^{1}$ Miftah Khilmi Hidayatulloh ${ }^{2}$ \\ ${ }^{1}$ Program Studi PG PAUD FKIP, 2Program Studi Tafsir Hadist Fakultas Agama Islam \\ Universitas Ahmad Dahlan \\ intan.puspitasari@pgpaud.uad.ac.id¹,_miftah@ilha.uad.ac.id²
}

\begin{abstract}
: story telling is one method for instilling moral -spiritual values in early childhood. The method of storytelling is effective to be done in early childhood because children are at the level of fairy tale (fairy tale stage) in the stage of spiritual development. At this stage children are attracted to amazing stories so that they develop their imagination. This condition can be used by parents and educators to be able to instill various moral-spiritual values in children through a story. To attract the interests of children, stories can be told in various ways that are more in line with the progress of the current era. Two of them are with interactive media and story-telling story acting. The Qur'an as a guide to the lives of Muslims is full of lessons that are contained in the words of God. As for some of these lessons delivered through the story of the Prophet, previous people and the stories of animals. This article is a written idea that discusses moral messages that can be taken from the fable characters in Surat AlFiil. The discussion of this article is carried out with a literature review using psychological reviews through the theory of moral-spiritual development and interpretation of the Koran. The purpose of this article is to provide new insights about instilling moral values in children by conveying moral messages from fable stories in the Qur'an
\end{abstract}

Keywords : moral values, fable stories, Al-Fill, Early Childhood

\begin{abstract}
Abstrak. Bercerita merupakan salah satu metode untuk menanamkan nilai moralspiritual pada anak usia dini. Metode bercerita efektif untuk dilakukan pada anak usia dini karena anak sedang berada pada tingkat dongeng (fairy tale stage) dalam tahap perkembangan spiritualnya. Pada tahapan ini anak tertarik dengan cerita menakjubkan sehingga mengembangkan daya imajinasinya. Kondisi ini dapat dimanfaatkan oleh orang tua maupun pendidik untuk dapat menanamkan berbagai nilai moral- spiritual pada anak melalui sebuah cerita. Untuk menarik minat anak, cerita dapat disampaikan dengan berbagai cara yang lebih sesuai dengan kemajuan zaman saat ini. Dua diantaranya adalah dengan media interaktif dan story tellingstory acting. Al quran sebagai pedoman hidup umat Islam sarat akan pelajaran yang tertuang dalam firman-firman Allah. Adapun beberapa pelajaran tersebut disampaikan melalui kisah Nabi, umat terdahulu maupun kisah-kisah binatang. Artikel ini merupakan gagasan tertulis yang membahas tentang pesan-pesan moral yang dapat diambil dari karakter fabel dalam Surat Al-Fiil. Metode yang dilakukan dalam pembuatan artikel ini dilakukan dengan literature review menggunakan tinjauan psikologi melalui teori perkembangan moral- spiritual dan tafsir Al Quran. Tujuan dari artikel ini adalah memberikan wawasan baru mengenai penanaman
\end{abstract}




\section{WACANA}

nilai moral pada anak dengan menyampaikan pesan-pesan moral dari cerita fabel dalam Al Quran.

Kata kunci: Nilai Moral, Cerita Fabel, Surat Al-Fiil, Anak Usia Dini

\section{PENDAHULUAN}

Bercerita adalah metode belajar yang menyenangkan bagi anak. Anak mendapatkan pemahaman baru mengenai diri dan lingkungannya melalui penuturan kisah yang terinspirasi dari tokoh pendahulu maupun tokoh fiktif (Ahyani, 2010). Kemampuan berimajinasi dan berpikir kritis pada anak juga dapat ditingkatkan melalui metode ini (Sanchez \& Lambert, 2009). Unsur-unsur afektif seperti empati, motivasi maupun menghormati orang lain dapat diasah ketika anak mendapat pemaparan cerita yang menarik dan dekat dengan kehidupan sehariharinya.

Bercerita dapat menjadi salah satu metode dalam menanamkan nilai-nilai moral pada anak usia dini (Rahim dan Rahiem, 2012). Menurut teori belajar sosial (Bandura, 1971) anak usia dini berada pada tahap imitatif atau modelling yaitu cenderung meniru apa yang dilihat maupun di dengar. Guru maupun orangtua dapat menunjukkan atau membiasan perilaku tertentu agar menjadi perilaku yang melekat pada anak. Terlebih apabila orang dewasa memberi penguat (reinforcement) berupa reward atau pujian ketika anak menunjukkan perilaku yang diharapkan, perilaku tersebut akan diulang kembali di kemudian hari. Cerita yang mengandung nilai-nilai moral yang positif dapat menjadi model bagi anak untuk ditiru. Anak akan berpikir bahwa dirinya juga mampu untuk berbuat baik seperti karakter maupun pesan yang ada pada cerita tersebut (Borba, 2001).

Penanaman nilai-nilai moral idealnya mendapat perhatian khusus bagi semua pihak yang berperan dalam tumbuh kembang anak usia dini seperti keluarga, lingkungan, sekolah, dan sistem masyarakat. Perlu memperhatikan beberapa aspek pada diri anak sebagai penentu keberhasilan penanaman nilai moral tersebut. Menurut teori perkembangan moral Piaget (dalam Shaffer, 2009) anak usia 0-5 tahun berada pada tahapan periode premoral. Pada tahap periode premoral ini anak cenderung tidak mematuhi peraturan yang telah ditetapkan melainkan mengikuti aturannya sendiri yang menurutnya lebih menyenangkan. Berdasarkan teori tersebut, sebagai pendidik maupun pengasuh anak usia dini sebaiknya 


\section{WACANA}

menyampaikan nilai-nilai moral yang dengan cara yang disukai anak sehingga anak mempunyai peluang lebih besar dalam menerapkan nilai-nilai tersebut.

Nilai-nilai moral pada umumnya lekat dengan ajaran agama. Karakteristik perkembangan agama pada anak usia dini juga harus dipahami ketika menyampaikan ajaran yang memuat nilai moral. Ernest Harms dalam The Development of Religious on Children (1944) mengungkapkan bahwa kepercayaan anak usia 3-6 tahun masih dipengaruhi oleh fantasi dan emosi yang didapat dari dongeng-dongeng tidak real. Pada tingkatan ini mengajarkan moral dan agama pada anak melalui dongeng merupakan metode yang tepat.

Saat ini semakin banyak peristiwa di masyarakat yang menunjukkan kemerosotan moral anak bangsa. Tidak hanya pada tataran remaja saja, namun meningkatnya penyimpangan perilaku moral juga muncul pada anak usia dini. Misalnya pada tahun 2016 di Lampung terdapat kasus bullying yang dilakukan oleh anak TK pada teman sekolahnya. Pelaku merebut bekal makanan korban kemudian diinjak-injak, merampas uang saku, serta mendorong hingga korban jatuh (Sulis, 2016). Syarifah (2014) mengungkapkan bahwa Komisi Perlindungan Anak Indonesia (KPAI) mendapat beberapa laporan kasus moral yang terjadi di playgroup seperti perilaku kekerasan dan sikap menghasut yang termasuk dalam tindakan bullying. Seperti yang diungkapkan sebelumnya, perilaku anak usia dini cenderung meniru apa yang dilihat atau didengarnya. Dalam hal ini, tentu setiap pihak yang berinteraksi langsung dengan anak menjadi salah satu faktor yang berpengaruh terhadap baik buruknya perilaku anak. Penurunan nilai moral ini jika tidak dicegah akan menimbulkan berbagai dampak negatif bagi anak baik fisik maupun psikisnya.

Al-Quran sarat akan hikmah yang harus dijadikan pedoman hidup bagi umat muslim. Dalam Al-Quran terkandung berbagai kisah yang mengandung hikmah sebagai petunjuk manusia untuk berbuat baik dan bermoral. Misal dalam Q.S Luqman: 17 Allah berfirman yang artinya:

"(Luqman berkata) Wahai anakku! Laksanakanlah sholat dan suruhlah (manusia) berbuat yang makruf dan cegahlah (mereka) dari yang mungkar dan bersabarlah terhadap apa yang menimpamu, sesungguhnya yang demikian itu termasuk perkara yang penting."

Ayat di atas menjelaskan bahwa seluruh manusia memiliki kewajiban untuk mensyiarkan dan mengajar satu sama lain dalam kebaikan sehingga tidak ada lagi 


\section{WACANA}

perbuatan buruk di muka bumi. Dalam hal pendidikan anak usia dini, baik orangtua maupun seluruh pihak yang terlibat mempunyai kewajiban untuk menanamkan nilai-nilai moral pada anak dengan cara yang dimengerti anak.

Praktik penanaman nilai moral pada anak usia dini dengan metode bercerita memang sudah umum dilakukan. Secara spesifik, cerita yang umumnya digunakan sebagai bahan pembelajaran nilai moral untuk anak adalah kisah umat terdahulu, nabi, dan rasul. Pemberitaan dalam Al-Quran tentang umat terdahulu, nubuat (Kenabian), dan peristiwa yang benar-benar terjadi di zaman dahulu, menurut Manna' Khalid al-Qattan disebut dengan Qashash (Caheruddin, 2016). Qashash ini terkandung dalam Al-Quran sebagai pelajaran berharga bagi kehidupan manusia.

Al-Quran juga mengajarkan nilai-nilai moral melalui kisah fabel. Sebagaimana yang kita ketahui bahwa beberapa nama surat dalam Al-Quran adalah nama-nama binatang seperti Al Baqarah (sapi betina), An-Nahl (lebah), An-Naml (semut), AlAddiyat (kuda perang), Al-Fiil (gajah), dsb. Jika dikaji dengan pendekatan tafsir maka manusia akan mudah memahami tentang kandungan surat tersebut berdasarkan asbabun nuzul (sebab turunnya ayat) maupun makna atau pelajarannya. Kisah fabel dalam Al-Quran ini dapat digunakan untuk menanamkan nilai moral pada anak. Namun menurut penelusuran sumber yang dilakukan penulis, jumlah pengkajian penanaman moral berbasis cerita fabel dalam Al-Quran masih terbatas.

Surat Al-Fiil merupakan salah satu surat yang menceritakan tentang hewan yaitu gajah. Dalam surat ini terkandung pembelajaran nilai moral untuk anak usia dini seperti mencegah diri dari mengambil hak orang lain dan tidak bersikap sombong. Selain itu anak dapat memahami karakter dan perilaku hewan dalam surat Al-Fiil. Pesan moral dalam surat Al-Fiil dapat disampaikan melalui berbagai strategi agar menarik bagi anak usia dini seperti media-media interaktif.

Cerita fabel dalam Al-Quran ini dapat menjadi alternatif bagi oramgtua maupun guru dalam menanamkan nilai moral pada anak. Cerita fabel dalam AlQuran benar-benar terjadi pada zaman dahulu sehingga fantasi anak bertemu dengan kenyataan. Selain itu, anak akan lebih mengenal dan dekat dengan Al-Quran sejak dini untuk membentuk karakter yang religius. 


\section{WACANA}

\section{PEMBAHASAN DAN DISKUSI}

\section{Perkembangan Moral dan Spiritual Anak Usia Dini}

Moral merupakan salah satu aspek dalam perkembangan sepanjang hidup manusia selain kognitif, afektif, psikomotor maupun sosial-emosi. Perkembangan moral berbicara tentang aturan dan kepercayaan yang seharusnya dilakukan oleh manusia ketika berinteraksi dengan orang lain di tempat tertentu (Santrock, 2002). Umumnya suatu perilaku dipandang bermoral atau tidak tergantung pada adat dan kesepakatan yang berlaku di tempat tersebut. Sangat memungkinkan suatu perilaku dipandang tidak bermoral di suatu tempat namun di tempat lain perilaku tersebut dinilai sebagai perilaku yang normal. Meskipun pada aturan yang bersifat kemanusiaan atau hubungan antar sesama manusia nilai moral dipandang universal seperti saling menghormati, tidak mengambil hak orang lain, dan bersikap adil.

Pembahasan mengenai perkembangan moral anak usia dini meliputi anak berusia 3 hingga 7 tahun. Jean Piaget sebagai salah seorang tokoh psikologi secara intensif melakukan observasi dan wawancara pada anak usia 4-12 tahun ketika mereka bermain kelereng. Dari pengamatan tersebut diketahui bahwa anak berusia 4-7 tahun berada pada tahap moral heteronom yaitu pandangan bahwa aturan adalah sesuatu yang tidak boleh diubah dan pelanggaran yang dilakukan terhadap aturan harus diberi hukuman segera. Anak usia 4-7 tahun akan tampak sangat khawatir ketika melakukan pelanggaran dan melihat sekeliling apabila ada yang melihatnya melakukan kesalahan tersebut sekaligus mengantisipasi hukuman yang akan diterimanya (Santrock, 2002).

Penekanan observasi Piaget di atas berada pada sikap anak terhadap aturan dan perilaku ketika melanggar peraturan tersebut. Anak memiliki kepercayaan diri ketika mematuhi aturan dan takut ketika melanggar peraturan karena adanya hukuman. Pada usia ini, anak menilai baik atau buruk suatu perbuatan bukan berdasarkan tujuan suatu perbuatan namun lebih kepada akibat atau hasil dari perbuatan tersebut (Shaffer, 2009). Begitu juga ketika berperilaku, anak akan cenderung fokus pada aturan yang berlaku agar tidak menerima hukuman.

Hal ini sesuai dengan tahap perkembangan moral yang ditawarkan Kohlberg. Pada tahap orientasi hukuman dan ketaatan (punishment and obidience orientation) 


\section{WACANA}

anak taat karena orang-orang dewasa menuntut mereka melakukan hal tersebut dan agar terhindar dari hukuman. Selain itu ketika berhasil memenuhi peraturan mereka memiliki harapan untuk mendapatkan imbalan tertentu. Hal ini yang terjadi pada tahap individualisme dan tujuan (individualisme and purpose). Pada akhirnya, ketika anak melakukan hal yang baik atau buruk mereka telah mengetahui akibat dari perbuatan tersebut. Mereka merasa senang ketika mendapat panggilan "anak baik" karena taat pada aturan dan merasa sedih ketika mendapat panggilan "anak nakal" ketika melanggar aturan (Shaffer, 2009).

Sejalan dengan teori perkembangan moral anak usia dini, praktik spiritual anak usia dini juga masih terkait dengan menaati aturan dan takut akan hukuman. Mayoritas anak melakukan praktik-praktik ibadah karena menghindari hukuman dari orangtua maupun hukuman dari agama yang dipeluk. Misalnya anak beribadah karena takut mendapat marah orangtua jika tidak melaksanakan selain itu takut akan neraka sebagai hukuman puncak jika melanggar ajaran agama. Pada tahap ini anak usia 3-6 tahun masih terpesona dengan dongeng imajinatif yang membuat anak mudah percaya dengan cerita yang didengarnya. Karakteristik spiritual ini menjadi salah satu celah untuk menyisipkan nilai-nilai moral positif melalui cerita. Anak akan lebih memahami perbuatan yang benar dan yang salah kemudian menirunya.

Karakteristik perkembangan moral anak usia dini yang telah disebutkan di atas menunjukkan bahwa tidak ada area perbuatan yang bersifat abu-abu. Anak hanya akan menilai suatu perbuatan sebagai baik dan buruk. Hal ini menjadi salah satu titik penting bagi penanaman nilai moral paling mendasar pada anak usia dini. Anak harus bisa membedakan perbuatan yang baik dan buruk sejak dini terlebih dahulu (Ahyani, 2010), meskipun seiring dengan perkembangan pada aspek lain pandangan anak tentang suatu sikap dapat lebih leluasa. Oleh karena itu baik orangtua maupun guru perlu memahamkan pada anak usia dini bahwa perbuatan salah memang salah dan perbuatan baik memang baik, sehingga anak tidak mengalami kebingungan konsep moral. 


\section{WACANA}

\section{Bercerita Untuk Menanamkan Nilai Moral Anak}

Aspek moral pada anak dapat berkembang secara optimal apabila mendapat stimulus yang maksimal. Stimulus atau rangsangan yang maksimal dapat dilakukan dengan memperhatikan tingkat capaian perkembangan yang lain seperti kognitif dan sosial-emosinya. Metode dan pendekatan yang tepat merupakan hal yang penting dalam memberikan stimulus bagi perkembangan anak. Seperti yang telah diungkapkan oleh penulis, dalam menanamkan nilai moral pada anak perlu memperhatihan karakter perkembangan moral anak itu sendiri.

Salah satu cara menanamkan nilai dan moral pada anak adalah melalui dongeng atau cerita yang saat ini mulai banyak ditinggalkan oleh orangtua. Saat ini anak lebih akrab dengan teknologi dan gawai dengan berbagai media tontonan dibandingkan mendengarkan dongeng atau cerita yang disampaikan oleh orangtuanya. Beberapa konten dari tontonan tersebut bahkan tidak cocok untuk dikonsumsi oleh anak usia dini. Padahal dengan dongeng, orangtua dan anak dapat membangun ikatan dan interaksi yang kuat sehingga anak lebih mudah untuk menerima nasihat mengenai permasalahan sehari-hari (Haryadi \& Irawan, 2016).

Vitz (1990) mengatakan bahwa narasi dan berpikir naratif sangat terlibat dalam sebuah proses yang mengarah pada perkembangan moral dan oleh karena itu cerita narasi harus ditinjau kembali sebagai bagian dari pendidikan moral. Meskipun pada kenyataannya penggunaan cerita atau dongeng memiliki tujuan yang berbedabeda, ada hubungan yang kuat antara bercerita dan nilai-nilai karena pada mulanya kegiatan bercerita digunakan untuk pendidikan dan perkembangan moral (Kweh, 2016). Kohlberg (1981) sebagai tokoh psikologi yang memelopori teori perkembangan moral juga menentukan tingkatan-tingkatan moral individu berdasarkan pertimbangan individu tersebut terhadap kasus dalam sebuah cerita.

Anak harus dapat membedakan benar dan salah sejak dini. Metode bercerita mengandung aspek-aspek yang dibutuhkan dalam perkembangan psikologis anak seperti berpikir kritis, mengasah emosi dan belajar nilai-nilai moral. Melalui ceritacerita tersebut anak belajar pada karakter dan pengalaman tokoh sehingga anak memiliki panutan dalam perilaku baik yang dibawa hingga ia dewasa (Ahyani, 2010). Penelitian yang dilakukan Ahyani (2010) ini menunjukkan hasil bahwa 


\section{WACANA}

terdapat perbedaan tingkat kecerdasan moral pada anak yang mendapat penyampaian nilai-nilai moral melalui metode bercerita dan yang tidak. Anak yang mendapat penyampaian nilai moral melalui metode bercerita memiliki kecerdasan moral yang lebih tinggi dibandingkan kelompok kontrol.

Sanchez (2009) mengungkapkan bahwa metode bercerita dapat meningkatkan kreatifitas dan daya kritis anak. Tokoh yang berperan dalam sebuah cerita memiliki karakter-karakter tertentu yang dapat merangsang daya imajinasi, empati, memahami orang lain sekaligus menyerap pesan nilai dan moral yang terkadung dalam cerita tersebut. Anak juga akan mendapat pemahaman bahwa orang yang berbuat baik akan mendapat kebahagiaan sedangkan orang yang berbuat buruk akan berakhir dengan kesengsaraan sebagaimana yang pada umumnya dikisahkan dalam cerita dan dongeng (Chaeruddin, 2016).

Berdasarkan teori-teori perkembangan moral yang dikemukankan oleh Piaget, Kohlberg dan Harms maka dapat diasumsikan bahwa anak akan lebih mudah menerima pesan-pesan moral melalui cerita. Terlebih anak usia dini berada pada tahapan fairy tale yaitu menyukai kisah-kisah menakjubkan terlebih jika disampaikan dalam cara-cara yang menarik. Sebagaimana Al-Quran yang memiliki berbagai kisah dari umat terdahulu dan para nabi untuk seluruh manusia agar dapat diambil pelajaran mengenai baik dan buruk.

\section{Kisah dan Pesan Moral Surat Al Fiil}

Kisah dalam Surat Al-Fiil

Surat ini bercerita tentang seorang Raja Yaman yang bernama Abrahah bin AlShabah Al-Asyram dan tentaranya. Meraka menggunakan gajah sebagai alat perang dan kendaraan menuju Mekah. Karenanya, pasukan ini disebut dengan kata ashāb al-fil yang berarti "pemilik gajah". Tidak diterangkan lebih lanjut jumlah detil pasukan dan gajah yang dipersiapkan untuk menghancurkan kakbah ini (Wahbah, 30, h. 406).

Pasukan ini hendak menyerang Mekah dengan tujuan menghancurkan kakbah. Penyerangan ini dilatarbelakangi motivasi ekonomi dan politik. Kakbah kala itu sudah menjadi tempat tujuan banyak orang dari berbagai daerah. Abrahah berkeinginan memperkuat dominasi politiknya di kawasan dan keutungan ekonomi 


\section{WACANA}

negaranya. Maka ia membangun gereja besar yang dinama Qillis (القّلّس) sebagai objek kunjungan masyarakat luar kawasan ke daerahnya. Hal ini diharapkan dapat memperkuat politik dan ekonomi Negara yang ia kuasai.

Penyerangan kakbah dilakukan untuk mendukung rencana pencitraan gereja Qillis (القلّبس). Pasca hancurnya kakbah, diharapkan peziarah kakbah mengubah haluannya menuju Yaman. Sehingga Yaman akan mendapatkan banyak devisa dan semakin kokoh dominasi politiknya. Rencana ini dilakukan pada tahun $571 \mathrm{M}$, bertepatan dengan tahun kelahiran Nabi Muhammad SAW. Maka peristiwa ini sering disebut sebagai irhash oleh beberapa kalangan.

Pasukan gajah segera mendatangi Mekah. Tidak ada pasukan perlawanan yang disiapkan penduduk Mekah untuk menahan invasi ini. Namun, sebelum Abrahah memasuki Mekah, pasukannya dihalau oleh burung-burung yang berkelompok membawa batu panas pada paruh dan 2 kakinya. Kemudian batu tersebut dijatuhkan ditengah-tengah pasukan gajah. Batu panas ini sangat mematikan, sehingga baik manusia maupun gajah yang dijadikan alat perang, akan mati jika terkena batu panas ini.

Peristiwa tersebut merupakan peristiwa ajaib yang dalam khazanah Islam dikenal dengan nama khawāriq lil ādah. Yaitu, sebuah peristiwa ajaib yang tidak sesuai dengan hukum alam, bentuknya ada beberapa macam, seperti: irhash, mukjizat, karamah dan sihir. Peristiwa ini dikenal dengan nama irhash. Yaitu sebuah peristiwa ajaib yang menandai lahirnya manusia yang luar biasa.

\section{Karakter Fabel dalam Surat Al Fil dan Perilakunnya}

Ada dua binatang yang menjadi tokoh dalam kisah di atas. Pertama adalah gajah, dan yang kedua adalah burung. Gajah adalah hewan yang besar dan kuat. Hewan ini digunakan sebagai kendaraan perang oleh sebagian masyarakat karena kekuatannya. Maknanya, sekuat dan sebesar apapun gajah, tetap dapat dikendalikan oleh manusia yang walaupun jauh lebih kecil, namun memiliki kecerdasan yang jauh lebih unggul dari pada gajah. Ini menunjukkan bahwa ilmu itu lebih unggul dari pada kekuatan. Karena gajah yang kuat bisa dikuasai oleh manusia yang berilmu.

Posisi gajah dalam kisah ini netral. Walaupun kuat, dalam kisah ini terlihat gajah adalah makhluk yang lemah dihadapan manusia yang menguasainya. Sehingga 


\section{WACANA}

gajah-gajah ini harus menuruti apapun kehendak tuannya, yaitu bergerak menuju Mekah untuk menghancurkan kakbah. Maka ada hikmah yang sangat penting diambil dari hubungan gajah dan pasukan ini. Bahwa makhluk yang kuat namun tidak berilmu dapat dikuasai oleh tuannya yang berilmu. Makhluk kuat ini berbuat sekehendak tuannya, bahkan untuk berbuat jahat sekalipun.

Binatang kedua yang disebutkan dalam kisah ini adalah burung. Burung adalah hewan yang memiliki banyak spesies. Ada yang besar da nada yang kecil. Burung berbadan besar biasanya merupakan binatang karnivora yang suka memangsa binatang lainnya. Sedangkan burung berbadan kecil biasanya binatang herbivore yang mengkonsumsi biji-bijian. Hewan ini banyak yang memiliki suara dan bulu yang indah. Sehingga di Indonesia banyak orang yang menjadikannya sebagai hewan piaraan karena keindahannya.

Seindah apapun burung itu, dalam kisah ini terlihat burung itu menjadi hewan yang menakutkan. Mereka datang secara bergerombol dengan membawa batu yang mematikan. Burung seperti ini tidak seperti burung lainnya yang terlihat indah. Ini merupakan peristiwa non empirik yang dapat menimpa saja kepada orang-orang zalim yang dikehendaki Allah SWT. Artinya, sekecil dan selemah apapun seekor hewan dapat berubah menjadi mematikan bahkan bagi satu pasukan sekalipun jika Allah berkehendak.

\section{Penyampaian Cerita Fabel dalam Al Fiil}

Bercerita atau dalam bahasa inggris disebut dengan storytelling sebenarnya sudah ada sejak zaman dahulu. Para orangtua bercerita tentang berbagai kisah, mitos, legenda maupun fabel kepada anak-anaknya sebagai pengantar tidur dimana ini menjadi cara orangtua menanamkan nilai-nilai. Haryadi dan Irawan (2016) menyebutkan bahwa manfaat yang didapat dari kegiatan bercerita antara lain 1) mengembangkan imajinasi anak; 2) meningkatkan keterampilan bahasa; 3) meningkatkan minat baca; 4) membangun kecerdasan emosional; dan 5) membentuk sifat empati anak.

Saat ini telah terjadi pergeseran zaman dan gaya hidup pada generasi muda. Anak usia dini secara intensif terpapar pada kemajuan teknologi dengan segala daya tarik yang ditawarkan. Cerita-cerita yang dulu pernah populer kini tergantikan oleh 


\section{WACANA}

film-film animasi yang sebagian mengandung unsur kekerasan yang sayangnya lebih menarik bagi anak. Anak juga lebih tertarik untuk bermain gim dalam gawai dibandingkan bercakap-cakap dengan keluarga maupun orangtua. Generasi milenial memang sudah tak terelakkan lagi dari kebutuhan akan teknologi sehingga sebagai orangtua maupun pendidik perlu berinovasi supaya anak tertarik untuk menyimak penyampaian nilai-nilai moral tersebut (Saifulloh, Sulistyoningsih \& Lutfi, 2018).

\section{Media Interaktif}

Media buku merupakan salah satu model konvensional untuk menerapkan nilai moral pada anak usia dini. Buku merupakan media paling populer yang sampai saat ini paling mudah diterima oleh masyarakat. Selain itu buku menyajikan visual yang menarik bagi anak usia dini sehingga membuat imajinasi dan fantasi anak menjadi lebih konkret. Anak lebih tertarik pada media visual yang mudah dipahami dan didalamnya mengandung warna-warna cerah (Saifulloh, Sulistyoningsih \& Lutfi, 2018).

Saat ini telah banyak dikembangkan buku cerita anak berbasis teknologi. Melalui buku interaktif, anak diajak untuk terlibat aktif dalam proses belajar karena terjadi stimulus respon. Bintang, Waluyanto, dan Wahyudi (2018) mengembangkan sebuah buku interaktif tentang hewan landak. Selain menyajikan informasi tentang hewan landak, anak juga diberi fasilitas untuk dapat menjadikan hewan landak tersebut sebagai hewan peliharaannya. Media belajar interaktif ini menjadi alternatif bagi karakter anak yang cenderung mudah bosan. Menggunakan buku interaktif anak dapat belajar melalui visual bergerak yang disertai dengan suara pendukung. Komunikasi dua arah pada media tersebut akan lebih atraktif dan menyenangkan bagi anak (Saifulloh, Sulistyoningsih \& Lutfi, 2018).

Boneka interaktif saat ini juga mulai populer di kalangan orangtua yang ingin memberikan mainan edukatif bagi anaknya. Media ini dikemas dengan fisik karakter yang representatif sehingga tampak menarik bagi anak. Pada umumnya jika boneka berbentuk unta maka informasi di dalamnya juga berkaitan dengan hewan unta, dan sebagainya. Perangkat lunak yang memuat informasi lengkap terkait telah dipasang dalam boneka tersebut. 


\section{WACANA}

Kisah yang terkandung dalam surat Al Fiil dapat disajikan dalam sebuah media interaktif. Di dalamnya, anak akan belajar mengenai peristiwa serangan pasukan gajah dan burung ababil, karakter binatang yang ada dalam peristiwa tersebut beserta perannya serta pelajaran yang dapat diambil dari surat Al Fiil. Misalnya diceritakan dalam surat Al-Fiil bahwa meskipun memiliki fisik yang gagah dan kuat, pasukan gajah dipukul mundur dan kalah dari serangan burung ababil yang membawa batu-batu panas dari neraka. Melalui salah satu penggalan cerita tersebut, anak dapat diberi pemahaman bahwa kita tidak boleh merasa bangga dan paling hebat dibandingkan orang lain, karena kesombongan dapat membuat manusia lupa diri sehingga justru mendatangkan petaka bagi diri sendiri.

\section{Story Telling - Story Acting}

Melalui kegiatan story telling anak mendapat informasi dari orangtua maupun guru. Informasi tersebut dapat diperkuat dan lebih diresapi oleh anak dengan story acting, yaitu memperagakan cerita yang didengarnya. Anak dibebaskan untuk memilih karakter yang disukainya dan mereka ulang sebuah cerita. Nicolopoulou, McDowell, \& Brockmeyer (dalam Mardell, 2013) mengatakan bahwa story tellingstory acting merupakan cara terbaik untuk meningkatkan kreativitas, perkembangan sosial-emosional, serta keterampilan literasi. Dengan cara ini anak memiliki pengalaman menjadi karakter tertentu dan merasakan apa yang sekiranya dirasakan karakter tersebut.

Mardell (2013) mengatakan bahwa kunci dari kegiatan ini adalah listening atau mendengarkan yaitu guru/pengasuh mendengarkan anak, anak mendengarkan sesama atau teman, dan anak mendengarkan guru/pengasuh. Orangtua dapat menanyakan kepada anak bagian dari cerita yang manakah yang paling menarik kemudian mengaitkan satu pendapat dengan pendapat lainnya. Lebih jauh lagi anak diminta untuk mengungkapkan pendapat masing-masing mengenai karakter atau perilaku-perilaku yang terdapat dalam cerita. Hal ini dapat membantu menanamkan nilai-nilai moral pada anak secara exploratif.

Story telling-story acting ini dapat diterapkan pada surat Al-Fiil. Setelah mendengarkan pemaparan orangtua atau guru tentang surat Al-Fiil, anak diajak untuk bersama mengidentifikasi peran yang dimiliki oleh masing-masing karakter 


\section{WACANA}

kemudian untuk diperagakan dalam sebuah drama kecil. Anak diminta untuk merasakan peran yang dijalanainya baik sebagai gajah, burung ababil maupun pemeran yang lain.

\section{KESIMPULAN}

Surat Al-Fiil jika dipahami dengan pendekatan tafsir akan nampak berbagai pesan di dalamnya termasuk nilai-nilai moral. Pesan nilai moral dalam surat Al-Fiil dapat dilihat dari karakter-karakter fabel yang menunjukkan sikap serta peran masing-masing. Dalam hal ini karakter fabel yang diceritakan adalah binatang gajah dan burung ababil. Diceritakan bahwa gajah adalah hewan yang besar, gagah dan kuat. Namun dengan kekuatannya tersebut gajah tidak dapat menolak kehendak tuannya yang ingin meruntuhkan kakbah, sehingga ia menggunaan kekuatannya untuk menciptakan suatu kerugian. Di samping itu, burung ababil yang dinilai sebagai hewan kecil justru dapat memukul mundur pasukan gajah dengan membawa batu panas dari neraka. Burung ababil menjadi hewan yang mengerikan karena membawa batuan panas yang berasal dari neraka dan melemparkan bebatuan itu kepada pasukan gajah. Secara nilai moral, kisah ini menunjukkan bahwa 1) manusia seharusnya tidak memgambil bahkan merusak apa yang dimiliki orang lain, tindakan ini sama dengan mendzolimi orang lain, dan 2) manusia seharusnya tidak menyombongkan diri dari kekuatan atau kelebihan yang dimiliki, terlebih hingga memandang rendah orang lain. Menyombongkan diri dan merendahkan orang lain justru dapat menjatuhkan diri sendiri.

Menanamkan nilai moral dari surat Al-fiil dapat dilakukan dengan berbagai cara diantaranya dengan membuat media interaktif dan cara story telling- story acting. Dengan menggunakan media interaktif anak belajar dengan bantuan visual dan audio yang semakin menarik minat sehingga menghindarkan anak dari rasa kebosanan. Sedangkan dengan story telling-story acting anak dapat lebih menginternalisasi penanaman nilai moral dari cerita yang disampaikan dengan mengalami langsung berbagai karakter yang terdapat pada cerita. 


\section{WACANA}

\section{Daftar Pustaka}

Ahyani, L.N. (2010). Metode dongeng dalam meningkatkan perkembangan kecerdasan moral anak usia pra sekolah. Jurnal Psikologi Universitas Muria Kudus, 1(1), 24-32

Bandura, A. (1971). Social Learning Theory. New York: General Learning Corporation.

Bintang, I. S., Waluyanto, H. D., \& Wahyudi, A. T. (2018). Perancangan buku interaktif pengenalan landak mini sebagai alternatif hewan peliharaan bagi anak usia 46 tahun. Jurnal DKV Adiwarna, 2(11), 9.

Borba, M. (2001). Building Moral Intelligence. San Fransisco: Josey-Bass

Chaeruddin, B. (2016). Cerita sebagai metode penanaman nilai-nilai moral bagi anak. Inspiratif Pendidikan, 5(2), 253-262.

Harms, E. (1944). The development of religious on children. American Journal of Sociology, 50(2), 112-122

Haryadi, T. \& Irawan, D. (2016). Penanaman nilai dan moral pada anak sekolah dasar dengan pendekatan storytelling melalui media komunikasi visual. Andharupa, 2(1), 56-72

Kweh, S.H. (2016). The Use Of Stories As A Means Of Teaching Moral Development In Two Singapore Secondary Schools. Durham Theses, Durham University.

Rahim H. \& Rahiem, M.D.H. (2012). The use of stories as moral education for young children. International Journal of Social Sciend and Humanity, 2(6), 454-458

Saifulloh, K., Sulistyoningsih, M., \& Lutfi, M. (2018). Perancangan animasi interaktif pengenalan binatang pada anak usia dini. In Seminar Nasional Ilmu Pengetahuan dan Teknologi Komputer (Vol. 4, No. 1, pp. 253-258).

Sanchez, T \& Zam, G \& Lambert, Judy. (2009). Story-telling as an effective strategy in teaching character education in middle grade social studies. Journal for the Liberal Arts and Sciences, 13, 14-23.

Santrock, J.W. (2002). Life-Span Development (Perkembangan Sepanjang Hidup) Jilid I. Jakarta: Penerbit Erlangga

Shaffer, D. R. (2009). Social and Personality Development. Belmont Calif : Wadsworth.

Sulis, H. (2016). Kasus bullying di Lampung, anak TK rebut bekal temannya lalu diinjak-injak. Tribunlampung.co.id, Minggu 24 Januari 2016

Syarifah, F. (2014). Rupanya kasus bully sudah ada sejak di pendidikan usia dini. www.liputan6.com, 25 Maret 2014

Vitz, P. C. (1990). The use of stories in moral development: New psychological reasons for an old education method. American Psychologist, 45(6), 709-720. 